\title{
Health awareness among young women vaccinated against human papillomavirus infections
}

\section{Świadomość zdrowotna młodych kobiet zaszczepionych przeciwko wirusowi brodawczaka ludzkiego}

\author{
Beata Bąk, Marek Sikorski, Marzena Wrześniewska \\ Department of Nursing and Midwifery, Faculty of Heath Science, Jan Kochanowski University, Kielce, Poland \\ Head of Department: Prof. Grażyna Rydzewska MD, PhD
}

Key words: health, cancer, vaccination.

Słowa kluczowe: zdrowie, rak, szczepienia.

\begin{abstract}
Introduction: Genital human papillomavirus (HPV) infections are essentials factors in the development of cervical cancer. Human papillomavirus vaccines can contribute to reducing the high incidence of this disease, provided that this form of prophylaxis is commonly accepted. Participation in vaccinations is restricted by the belief that their implementation and consequent feeling of safety will reduce women's participation in other forms of cervical carcinoma prophylaxis and will encourage them to be sexually promiscuous.

Aim of the research study: To determine the awareness of cervical carcinoma prophylaxis among young women vaccinated against HPV by comparing them with a group of unvaccinated women.

Material and methods: The survey covered a group of 210 young women in the age range 18 to 20 years, who were vaccinated against HPV. Within the framework of comparison, the survey covered a group of 255 young HPV-unvaccinated women, adequately selected in respect of age and education.

Results: The HPVvaccinated women declared participation in medical check-ups and cytological tests no less frequently than the unvaccinated women. In both groups, the usage of condoms, sexual partners hygiene, monogamy and smoking abstinence were determined as behaviours limiting the occurrence of cervical carcinoma.

Conclusions: Awareness of the application of supplementary prophylaxis of cervical carcinoma was high among the HPV vaccinated woman and did not differ from the unvaccinated woman's awareness. Young women did not show a tendency for promiscuous behaviours, and were more likely touse condoms in the prevention of cervical carcinoma than were the unvaccinated woman.
\end{abstract}

\section{Streszczenie}

Wstęp: Genitalne zakażenia wirusem brodawczaka ludzkiego (human papillomavirus - HPV) są przyczyną rozwoju raka szyjki macicy. Szczepionki przeciwko HPV przyczynią się w przyszłości do obniżenia zachorowalności na raka szyjki macicy pod warunkiem powszechnej akceptacji tej formy profilaktyki. Udział w szczepieniach ograniczają przekonania, głównie rodziców nastolatek, dla których szczepionka jest przeznaczona, że jej implementacja i wypływajace z tego faktu poczucie bezpieczeństwa spowoduje, że kobiety nie będą stosowały innych form zapobiegania rakowi szyjki macicy, oraz zachęci je do promiskuitycznych zachowań seksualnych.

Cel pracy: Określenie świadomości konieczności stosowania profilaktyki w zakresie raka szyjki macicy wśród młodych kobiet zaszczepionych przeciwko HPV poprzez porównanie jej ze świadomością kobiet niezaszczepionych.

Materiał i metody: W badaniu zastosowano ankietę. Grupę badaną stanowiło 210 młodych kobiet w wieku 18-20 lat zaszczepionych przeciwko HPV. Ponadto ankietowano 255 młodych kobiet niezaszczepionych, odpowiednio dobranych pod względem wieku i wykształcenia.

Wyniki: Kobiety szczepione przeciwko HPV deklarowały udział w badaniach lekarskich i cytologicznych nie rzadziej niż te niezaszczepione. Stosowanie prezerwatyw, higiena partnerów seksualnych, monogamia oraz abstynencja nikotynowa zostały uznane w obu grupach kobiet za zachowania ograniczające występowanie raka szyjki macicy.

Wnioski: Świadomość konieczności stosowania uzupełniającej profilaktyki raka szyjki macicy jest wśród kobiet szczepionych przeciwko HPV wysoka i nie różni się od świadomości kobiet niezaszczepionych. Młode kobiety nie przejawiają tendencji do zachowań promiskuitycznych, a używanie prezerwatyw ma dla nich większe znaczenie w zapobieganiu rakowi szyjki macicy niż dla kobiet niezaszczepionych. 


\section{Introduction}

Cervical carcinoma is the second (after breast cancer) most frequently occurring malignant cancer among women in global statistics. In spite of the downward tendency in cervical carcinoma incidence and mortality observed in Poland over the last dozen or so years, these rates are still high in comparison with other countries [1].

Genital infections with human papillomavirus (HPV) are regarded as the most frequently occurring infections that are transmitted sexually [2]. Chronic infection in the uterine cervix epithelium is commonly regarded as an essential element of cancer development in this area, together with additional factors (high parity, nicotinism, long-lasting hormonal contraception, co-infections with other pathogens, immunity deficits and other poorly specified co-factors) may initiate cervical intraepithelial neoplasia (CIN). Loss of repressive control over the activity of viral oncogens (E6 and E7) relates as a rule to the creation of a pre-cancer epithelial phenotype (CIN2/3) with a high potential for stroma invasion $[3,4]$. A multistage epithelial transformation lasting at least a dozen or so years is initiated most commonly (in ca. 70\% of cases) by only 2 out of 15 oncogenic types of HPV virus - types 16 and $18[5,6]$. The vaccines currently available on the market are directed against these HPV types (bivalent vaccine - Cervarix) and additionally against types 6 and 11 (quadrivalent vaccine - Silgard) that are responsible for the formation of genital warts. The high effectiveness of prevention of intraepithelial uterine cervix changes connected with HPV infections of type 16, 18, 6 and 11 and a favourable safety profile - frequently shown in clinical tests - constitute a basis for recommending their use in programmes of active, primary cervical carcinoma prophylaxis in young teenage girls who have not started sexual relations yet [7]. However, there are limitations to actions of this type. Apart from factors of an economic nature, participation in vaccinations is lowered by serious reservations expressed by teenage girls' mothers and other environments engaged in youth education, according to which the vaccine's acceptance and the unjustified feeling of safety following the vaccination might reduce young women's participation in elementary forms of cervical cancer prophylaxis (cytological screening tests) and may also trigger risky sexual behaviours. Such opinions effectively contribute to the hampering of the development of vaccination programmes and constitute a starting point for many public debates [8-10].

\section{Aim of the research study}

A direct stimulus for conducting research was the conviction that improper behavioural patterns concerning pro-health behaviours may thwart the positive prophylactic effect of immunisation against HPV infections. It was assumed that HPV vaccination may trigger such unfavourable behavioural changes through generating an unjustified feeling of oncological safety.

The aim of the research was to determine the awareness of cervical carcinoma prophylaxis among young women vaccinated against HPV by comparing them with a group of unvaccinated women. The aim of the research was to ascertain whether HPV vaccinated women who were covered by the pre-vaccination education campaign in the field of cervical cancer prophylaxis are characterised, in comparison with the unvaccinated women, by a greater degree of promiscuity, revealing itself in earlier sexual initiation, having casual sexual relations and a greater number of sexual partners in life, lower motivation for participation in classical forms of secondary prophylaxis of cervical cancer (cytological tests) and a greater conviction about the health benefits resulting from smoking abstinence, a partner's intimate hygiene and the use of condoms. It was assumed that the obtained results would make it possible to evaluate the effects of the education campaign that accompanied vaccinations and identify the prophylactic areas that require modification.

\section{Material and methods}

A survey was used to examine a group of 210 young women aged 18-20 years from the municipality of Polkowice (Dolnośląskie Voivodeship) who received, at the age of 16 years, a quadrivalent HPV vaccine. The surveyed women were covered by the teenage girls vaccination program financed by the local government. The implementation vaccine was accompanied by a informative-educational campaign about protection against cervical carcinoma and promotion of such elements of a healthy lifestyle as abandoning stimulants, proper diet and avoiding sexually transmitted illnesses. Up to now, it has been the most homogeneous group of HPV vaccinated women in Poland. Within the framework of comparison, the survey covered a group of 255 young HPV unvaccinated women from Kielce, adequately selected in respect of age and education.

The project received approval from the Bioethical Commission of the Jan Kochanowski University in Kielce. In the statistical analysis the $\chi^{2}$ test was used.

\section{Statistical analysis}

The accepted level of significance was $\alpha=0.05$. The values of statistics with bilateral probability $p<\alpha$ were regarded as statistically significant.

\section{Results}

Results were presented on Figures 1-8. 


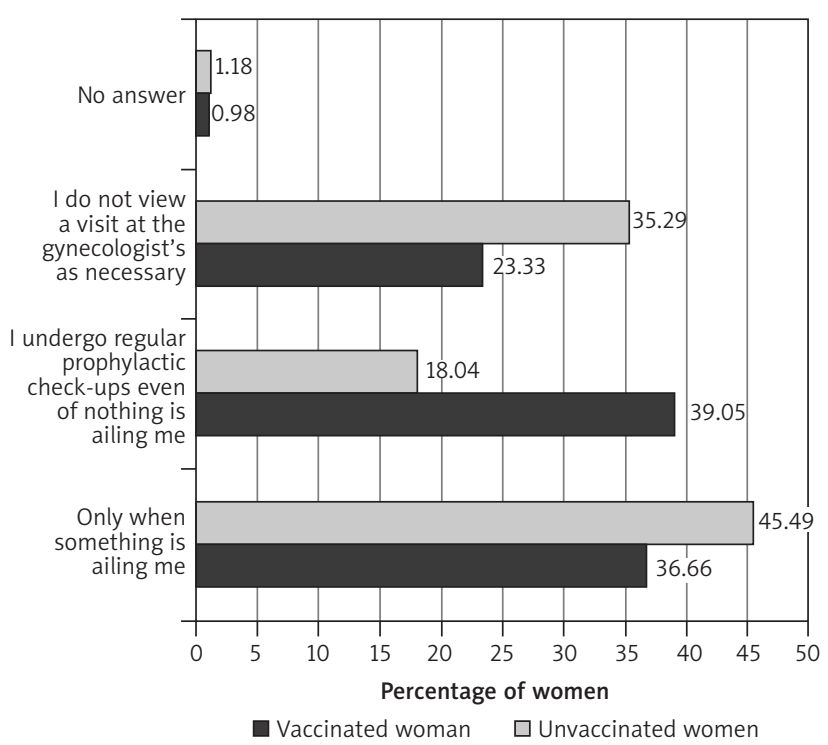

Figure 1. Frequency of visits to gynaecologist $(p<0.05)$

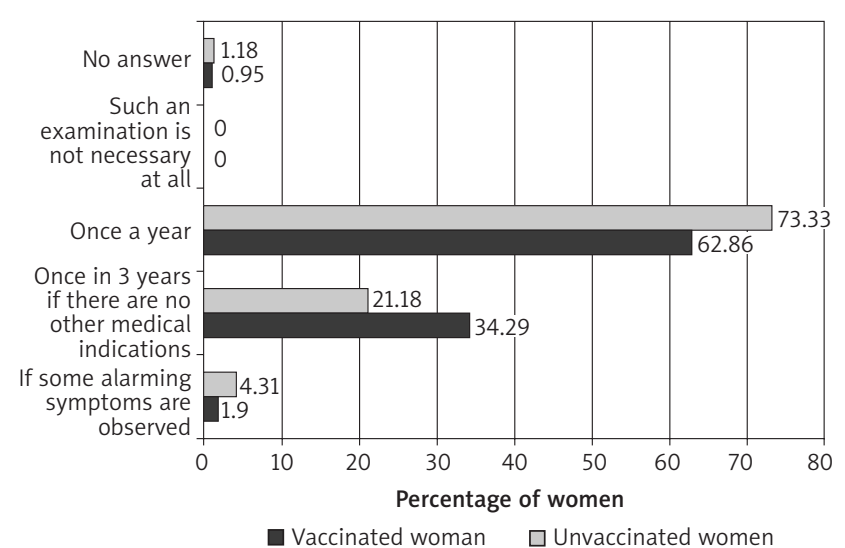

Figure 3. "In your opinion, how frequently should a mature woman go for a cytological examination for cervical cancer?" $(p<0.05)$

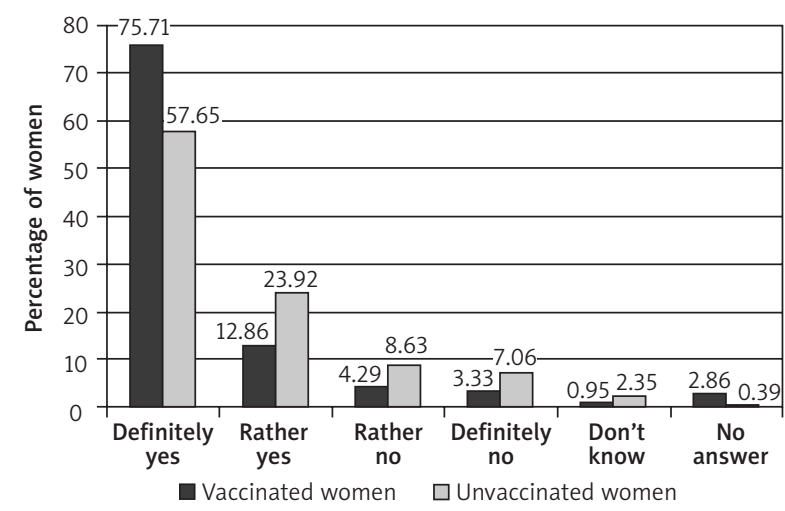

Figure 5. "In your opinion, does avoiding adventurous sexual intercourse limit the occurrence of cervical cancer?" $(p<0.05)$

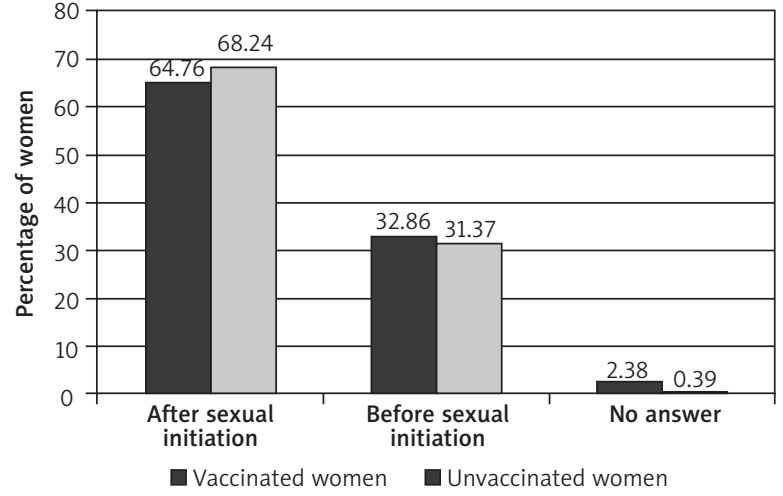

Figure 2. Percentage of women before and after sexual initiation $(p>0.05)$

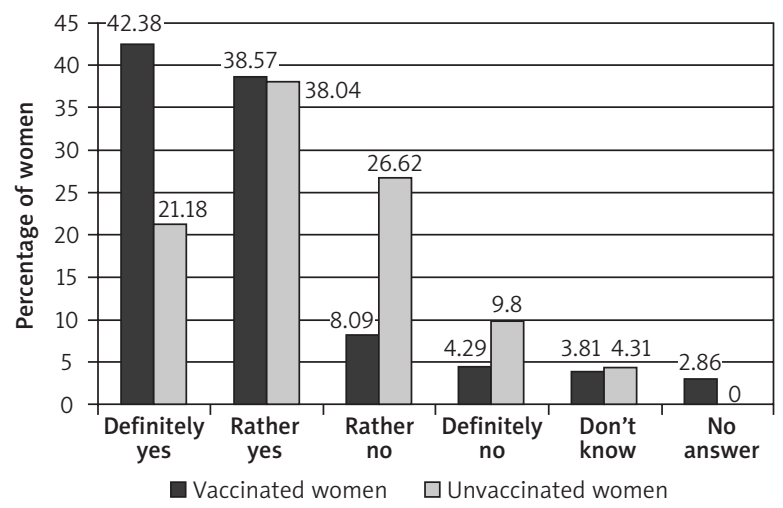

Figure 4. "In your opinion, does the use of condoms limit the occurrence of cervical cancer?" $(p<0.05)$

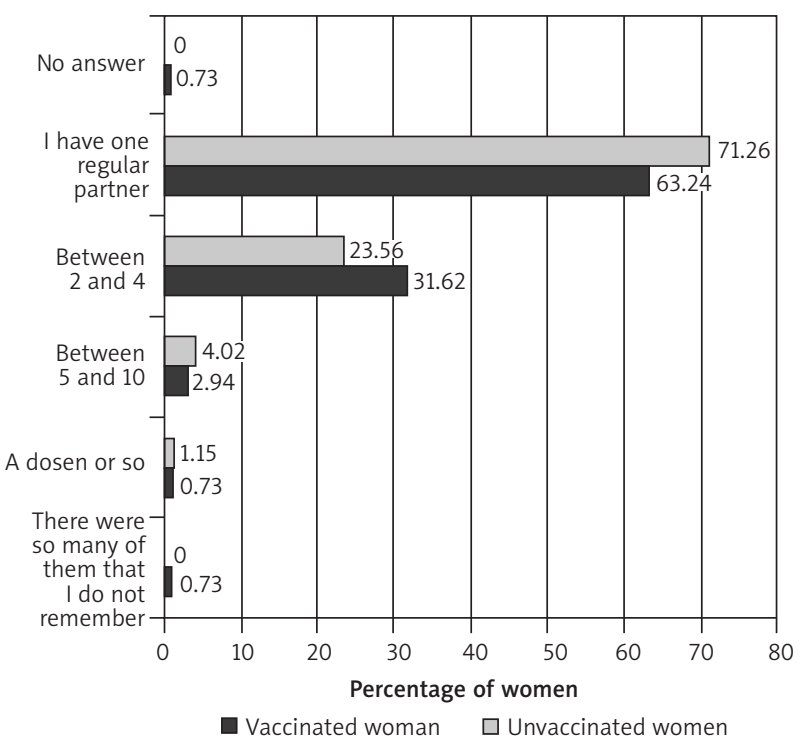

Figure 6. The number of sexual partners at the time of the survey $(p>0.05)$ 


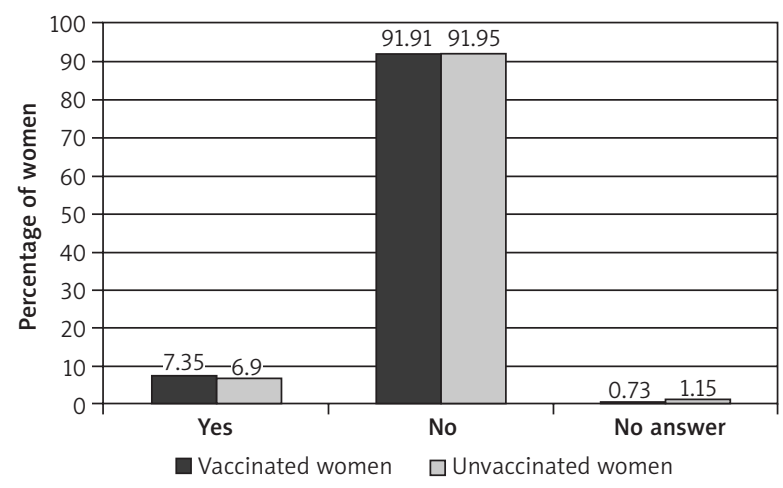

Figure 7. "I have sexual intercourse with a man other than my regular partner" $(p>0.05)$

\section{Discussion}

Cervical carcinoma prophylaxis is implemented by regular gynaecological examinations. The results (Figure 2), confirmed statistically, showed that young HPV vaccinated women are more aware of this fact than are unvaccinated women. This translates into a readiness to undergo a prophylactic test - even in the case of no existing ailments. It is a positive phenomenon in view of the fact, as Izdebski presents, that in Poland only $56 \%$ of women aged $15-59$ years visit a gynaecologist at least once a year [11]. However, it should be noted that in both groups the percentage of women who did not see the necessity of a gynaecological check-up is approximately equal to the percentage of those women who have not started their sex life yet (Figure 1). This might be the reason why these women do not take advantage of gynaecological tests which they should also have undergone before sexual initiation.

It has been proven that vaccine implementation does not appear in women's consciousness as a sufficient cervical carcinoma prophylaxis (Figure 3), which is of major importance, bearing in mind the fact that even effective immunisation against HPV leaves the vaccinated persons in the incidence risk group, even though this risk is decreased by about 70-80\%. Understanding the necessity for ongoing cytological supervision for the vaccinated persons plays a key role in preparing educational programmes that accompany teenage girls' immunisation [12].

The HPV vaccinated women present themselves quite well against a background of the general population of Polish women, who still participate insufficiently in prophylactic gynaecological tests. It should be noted that most of the surveyed women, both vaccinated and unvaccinated, would willingly make cytological tests once a year, despite the fact that answers compliant with specialists' recommendations (once in 3 years if there are no other indications) prevailed among the vaccinated women. It is difficult to

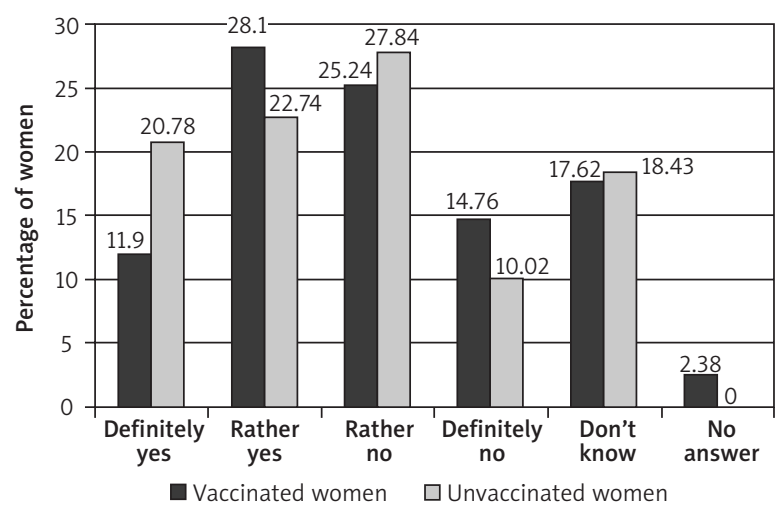

Figure 8. "In your opinion, does a non-smoking lifestyle limit the occurrence of cervical cancer?" $(p>0.05)$

assess health attitudes unambiguously in this case as the willingness to make a cytological check-up once a year is not a drawback; it is rather evidence of insufficient knowledge.

According to many specialists, conventional, regular cytological tests reduce the risk of becoming ill from cervical cancer by ca. $70 \%$ over the course of a woman's life, in the event she has not been HPV vaccinated. This result is comparable with the benefits of the HPV immunisation itself. If the tests are accompanied by routine vaccinations covering at least $80 \%$ of the population, it could, in the opinion of specialists, result in a decrease in the incidence rate of ca. 90\% [13]. Combining cytology with colposcopy increases the effectiveness of screening tests by up to $99 \%$ on average, hence some wealthy European countries have decided not to implement common prophylactic HPV vaccinations. An example of this is Finland, where a system of cytological screening tests has been functioning well for many years. After economic analysis, it was shown in this country that the costs of prospective common vaccinations would be equal to the costs of screening, hence they were abandoned [14]. According to Spaczyński et al., in Poland, as a moderately wealthy country, focus should be placed on conducting active and well-organised screening, while free vaccinations could be organised at local levels [15]. Common and compulsory vaccinations, possibly in the future, would not cause exemption from screening tests; they could only force modification of prophylactic programmes. Franco et al. proposed a model of a DNA HPV molecular test, whereas a cytological test in prolonged time intervals would be reserved for women with a positive HPV test result. The register of infected people, with increased risk of CIN development, would facilitate long-term cytological monitoring of women with a positive HPV test result [16].

It is interesting to note how the protective value of condoms is perceived in view of HPV infection risk. 
Global test results in this field are not explicit. A group of specialists are of opinion that although the application of condoms during sexual contact does not reduce the frequency of DNA HPV detection, it reduces the occurrence rate of genital warts, CIN2 and CIN3 changes, and an invasive type of cervical cancer [17]. Tests conducted in a population of couples, in which the women, as well as asymptomatic HPV infection, also CIN was found, and in the men, as well as asymptomatic infection, also genital warts were found, showed an important influence of consistent application of condoms both on the speed of morphological change regression in both partners and on shortening the duration of asymptomatic infection. The cumulated 2-year CIN regression rate and the remission rate of HPV infections in women in the group of couples using condoms, in comparison with couples not using them, was 53\% relative to $35 \%$, and $23 \%$ relative to $4 \%$, respectively [18]. On this basis, it is a promising sign that the HPV vaccinated women stated, significantly statistically more frequently than the unvaccinated women, that the application of condoms is a behaviour contributing to a reduction in cervical cancer occurrence (Figure 4), taking account of the fact that three-quarters of young persons in Poland and in the world treat this type of barrier as protection against unwanted pregnancy [19]. The vaccinated women present themselves better than Swedish students, whose sexual behaviours in 2009 and their evolution since 1999 are presented by Tyden et al. According to the said authors, during this decade the percentage of women who had their first sexual contact without a condom double and was $65 \%$. As many as $24 \%$ of respondents declared that they did not use a condom in their first contact with a new partner. Such behaviours have resulted in a 50\% rise in sexually transmitted infections in comparison with 1999 [20].

The HPV vaccinated women strongly declared, statistically more frequently than the unvaccinated women, that avoiding casual sexual contact contributes to a reduction in the cervical carcinoma incidence rate (Figure 5). Monogamic preferences dominated in both groups up to the time of the survey. Thus, the research did not show an impact of combined vaccination with the accompanying educational campaign that would generate promiscuous behaviours (Figures 6 and 7). In the above-mentioned research results of Tyden et al., 99\% of women were sexually active, out of whom only $57 \%$ remained in stable relationships. The average number of former sexual partners was as many as 11 and was double the number of partners from 10 years before.

Apart from behavioural factors, nicotinism is a cofactor of a lasting HPV infection, having a documented importance in the development of pathological changes in the uterine cervix. The results of the presented research showed that the HPV vaccinated young women do not have sufficient knowledge that nicotinism contributes to the increase in cervical cancer occurrence risk, a factor in which they do not differ from the unvaccinated women (Figure 8). Thus it is necessary to increase emphasis on the issue of nicotinism in the educational programmes that accompany vaccination implementation.

Since prophylactic HPV vaccinations concern teenage girls, it is the parents' decision whether or not to vaccinate their child. Taking into account the fact that the home is the first source of knowledge and the place where attitudes to health matters are formed, attention should be paid to parents as possible recipients of information, not only regarding the skill of conducting discussions on intimate matters but also on widening and updating their knowledge. It is also necessary to train gynaecologists, general practitioners, paediatricians, teachers and medical workers who most often deal with young patients and their parents.

\section{Conclusions}

The awareness and declared willingness to use the cervical carcinoma prophylaxis that accompanies HPV vaccination (regular cytological tests) are high in the group of vaccinated women and do not differ from the unvaccinated women's attitudes. The HPV vaccinated young women do not show any tendency for promiscuous sexual behaviour that is expressed by early sexual initiation, having casual sexual contact or a larger number of sexual partners, in comparison with the unvaccinated women. The HPV vaccinated women are more aware of the importance of using condoms in cervical carcinoma prophylaxis than were the unvaccinated women. The HPV vaccinations must be accompanied by health information and education that does not cause a false sense of safety.

\section{Acknowledgments}

This research was financed under the project entitled "Knowledge and Economy - Development of Science and Business Competence for the Increase in Competitiveness of the Regional Economy”. The project was co-financed by the European Union within the European Social Fund under the Human Capital Operational Program, Regional Human Resources for the Economy, Measure 8.3 Transfer of Knowledge and Sub-measure 8.2.1 Support to co-operation of scientific environment and enterprises.

\section{References}

1. Krajowy Rejestr Nowotworów. Centrum Onkologii - Instytut M. Skłodowskiej-Curie. Zakład Epidemiologii Nowotworów, http.//epid.coi.waw.pl./krn/, 2011.10.10.

2. Dunne EF, Unger ER, Sternberg M, et al. Prevalence of HPV infection among females in the United States. JAMA 2007; 297: 813-819. 
3. Bosch FX, Lorincz A, Munoz N, et al. The casual relation between human papillomavirus and cervical cancer. J Clin Pathol 2002; 55: 244-265.

4. Kjellberg L, Hallmans G, Ahren AM, et al. Smoking, diet, pregnancy and oral contraceptive use and risk factors for cervical intra-epithelial neoplasia in relation to human papillomavirus infection. Br J Cancer 2000; 82: 1332-1338.

5. Castellsague X, de Sanjose S, Aguado T, et al. HPV and cervical cancer in the world 2007 report. Vaccine 2007; 25: $1-26$.

6. Castellsague X. Natura history and epidemiology of HPV infection and cervical cancer. Gynecol Oncol 2008; 110 (3 Suppl 2): S4-S7.

7. Majewski S, Wysocki J, Sikorski M, et al.; Polish Society of HPV Infections Prophylaxis. Recommendations of the Polish Society of HPV Infections Prophylaxis - (PS-HPVIP) (Polskie towarzystwo profilaktyki zakażeń HPV - PTPZ HPV) concerning the use of preventive vaccines against HPV. Med Wieku Rozwoj 2008; 12: 621-625, 627-631.

8. Udesky L. Push to mandate HPV vaccine triggers backlash in USA. Lancet 2007; 369: 979-980.

9. Ogilvie G, Anderson M, Marra F, et al. A population-based evaluation of a publicly funded, school-based HPV vaccine program in British Columbia, Canada: parental factors associated with HPV vaccine receipt. PLoS Med 2010; 7: e1000270.; http://www.ncbi.nlm.nih.gov/pubmed, pobrano 2012.01.01

10. Ferris D, Horn L, Waller JL. Parental acceptance of a mandatory human papillomavirus (HPV) vaccination program. J Am Board Fam Med 2010; 23: 220-229.

11. Izdebski Z. Seksualność Polaków na początku XXI wieku. Wydawnictwo Uniwersytetu Jagiellońskiego, Krakow 2012.

12. Bernard DM, Cooper Robbins SC, McCaffery KJ, et al. The domino effect: adolescent girls' response to human papillomavirus vaccination. Med J Aust 2011; 194: 297-300.

13. Goldie SJ, Kohli M, Grima D, et al. Projected clinical benefits and cost-effectiveness of a human papillomavirus 16/18 vaccine. J Natl Cancer Inst 2004; 96: 604-615.

14. Torvinen S, Nieminen P, Lehtinen M. Cost effectiveness of prophylactic HPV 16/18 vaccination in Finland: results from a modelling exercise. J Med Econ 2010; 13: 284-294.

15. Spaczyński M, Malkowska-Walczak E, Nowak-Markwitz E, et al. Rola badania cytologicznego i testu DNA HPV w dobie szczepionki antywirusowej. In: Rak szyjki macicy. Profilaktyka, diagnostyka i leczenie. Spaczyński M, Kędzia W, Nowak-Markwitz E (eds.). Wydawnictwo Lekarskie PZWL, Warsaw 2009; 95-105.

16. Franco EL, Cuzick J, Hildesheim A, et al. Issues in planning cervical cancer screening in the era of HPV vaccination. Vaccine 2006; 24 (Suppl. 3): S171-S177.

17. Manhart LE, Koutsky LA. Do condoms prevent genital HPV infection, external genital warts, or cervical neoplasia? A meta-analysis. Sex Transm Dis 2002; 29: 725-735.

18. Hogewoning CJ, Bleeker MC, van den Brule AJ, et al. Condom use promotes regression of cervical intraepithelial neoplasia and clearance of human papillomavirus: a randomized clinical trial. Int J Cancer 2003; 107: 811-816.

19. Bretas JR, Ohara CV, Jardim DP, et al. Aspects of sexuality in adolescence. Cien Saude Colet 2011; 16: 3221-3228.

20. Tyden T, Palmqvist M, Larsson M. A repeated survey of sexual behavior among female university students in Sweden. Acta Obstet Gynecol Scand 2012; 91: 215-219.

\section{Address for correspondence:}

Beata Bąk MD, PhD

Faculty of Heath Science

Jan Kochanowski University

al. IX Wieków Kielc 19, 25-317 Kielce, Poland

Phone: +48 692113477

E-mail: beatab5@onet.eu 